\title{
README. DATA SET: TESTING PROTEST PARADIGM IN FEMICIDE PROTESTS IN MEXICAN PRESS
}

\author{
Author: Mariana Gutiérrez Aldrete
}

\section{Content:}

1. Data set description..............................................

2. Selection critera for newspapers and articles..........................

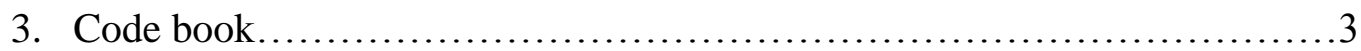

\section{Description}

This Data set consist of the coding of 2521 articles from national Mexican newspapers, composed by 1028 articles from El Universal, 966 from Reforma and 527 from Excélsior. It is corresponding to a research that analyzes the representation of the protests against femicide in Mexican press, and the opportunities reached by the social movement in the public discourse. Previous studies found tendency for negative representations of social movements in the media in the so-called 'protest paradigm', this means that the attention obtained not necessary guarantee the reproduction of movement's discourse. We use the paradigm approach and test the degree of adherence. It was registered the media attention to femicide issue for a period of 41 months in three national newspapers. The corpus was examined thorough using quantitative content analysis technique, with variables that measure the stories' emphasis, prominence, legitimation and tone for social movements and authorities, to compare between the two actors.

\section{Selection criteria for newspapers and articles}

The newspapers for the sample was chosen by the scope in audience; taking in account national coverage, daily print, visits to website and sort of editorial companies; and excluded specialized in finances, sports and entertainment. By using the tool Alexa.com to obtain the number of visits in the page and the ranking, the Government Secretary's inform about the daily print and a survey for the preferences in the audience select El Universal, Reforma and Excélsior.

El Universal is the news website with more visitors in México, eighth place in the daily printing rank, and is the most popular in the survey; Reforma is the third news website with more visitors, third in the printing rank, and second in the survey preferences; Excélsior is the second place for visitors in the website, eleven in daily printing, and sixth survey. Neither have an explicit political tendency at the time. 
We took the date of the first Alert of Gender Violence pronouncement as reference for the time limit in the study with the objective to compare the media attention before and after the policy, starting July 31 of 2014 (one year before) to December 31 of 2017 which covers 41 months.

The recollection of the articles was made completely from digital platform, using the searchers of the newspapers library with two criteria: introduce the word "femicide" (feminicidio), of the results and manually discard the articles in which the word was mention but the topic was unrelated to femicide, security, law or murders of women; the second search introduced the words "dead woman" (mujer muerta), of the results manually discard the articles in which the cause of death was proved no related with gender motives, the size of the sample is $\mathrm{N}=2521$. 
Readme. Data set: Testing Protest Paradigm in Femicide Protests in Mexican Press

\section{Code Book}

\section{Articles characteristics}

Register the title (column A) and the date (B).

\section{Problem definitions (C)}

1. Register (a) Social Problem: emphasis in statistics, increase, public policies, and laws.

2. Register (b) Isolated murders: articles with emphasis in particular cases about Authorities in action, findings death bodies and stories of murders.

Additionally register (SM) for emphasis in social movements, protests or NGOs actions; and (AA) for authorities actions.

Mixed news: Articles that informs both perspectives must be classified ' $a$ ' or ' $b$ ' using the emphasis of the title and/or counting the paragraphs dedicated to every perspective.

\section{Tone}

Actions are evaluated as positive, neutral or negative for mention as follow:

a) Authorities actions

(D) Register positive (1):

- Arrest the presumed aggressor.

- Convicted presumed aggressor.

- Presentation of new policies or laws.

- Other actions with positive appreciation.

(D) Register neutral (0):

- Investigate crimes without achievements. 
- Finding bodies.

- Positioning against the murders but no actions.

- Promise new policies.

(E)Register Negative (-1):

- Directly blame authorities as responsible for crimes (murders or human rights violations).

- Mention corruption, impunity, inaction, machismo, sexism, patriarchy or misogyny from authorities.

- Mention can't trust in authorities

- Mention of State Crime.

b) Social movement's actions

(F) Register positive (1)

- Claim justice for crimes.

- Claim appropriate investigations for the crimes.

- Statements to be against murders.

- Research made by a NGO.

- Human interest story about victims or families related with a protest.

- Mentions the aim of the NGO is helping victims and families.

- Proactive for pronouncement of Alert of Gender Violence.

- Positive appreciation of social movements or NGOs.

(F) Register neutral (0) 
- Proposals of new policies.

-Willingness to collaborate with authorities.

(G) Register negative (-1)

The authorities proved movements' claims are wrong.

- Their research has no basis.

- Aggressive behavior

- Detours and affectations in cars' circulations.

\section{Sources}

(H)Register the explicit quotes in the article as a Source.

a) Sentences in quotation marks.

b) Sentences written in first person attributable to an actor.

c) Attributes information to a specific source.

- Mentions the information was obtained from an actor in an interview, corporate communications documents, publications or press releases.

- Readable written messages in pictures attributable to an actor.

- If there is not source named, register as (No Source).

\section{Targeted Sources}
a) Authorities
1) Crime investigations Authority.
- Register (PGJE) Procuraduría General de Justicia of a State, Federal, Fiscalía and Fiscal. 
- Police

- Forensic services.

2) Gender Authority.

- Secretaría de Gobernación Federal (SeGob).

- Comisión Nacional para Prevenir y Eliminar la Violencia contra las Mujeres (CONAVIM).

- Instituto Nacional de las Mujeres (INM).

- Institutos locales de la Mujer (IME).

3) Statistics Authority.

- Instituto Nacional de Estadística y Geografía (INEGI).

- Secretariado Ejecutivo del Sistema Nacional de Salud Pública (SESNSP).

4) Representative

- Diputados/as and Senadores/as.

5) Judicial

- Supreme Court.

- Judges.

- Court workers.

6) Other Authority

- President

- Governors 
- Other

b) NGO and Activists.

- Local and international NGOs.

- National Civic Observatory of Femicide (OCNF).

- UN Women

- International Amnesty

- Register as Activist for activists, protesters, women and men in protests.

c) (Family) for mother, father, sister, brother and other members of the victims 'family.

\section{Statistics Source (I)}

- Register (1) from NGOs.

- Register (-1) from Authorities.

- Register (0) from both actors.

\section{Different information from actors}

(J) Register (1) for Different Views

- The information from authorities and social movements about statistics, classification of the crime, other topics differs in the same article, or different article but the relation is mentioned.

- Same as above in cases with follow up, even if is different article but is detected by the coder.

(K) Conflict

- (-1) Social movements, protestors or NGOs blames authorities of institutional violence. 
Readme. Data set: Testing Protest Paradigm in Femicide Protests in Mexican Press

- (1) Authorities blame social movements, protestors or NGOs of violence behavior or justice obstruction.

\section{Inside conflict}

(L) Register (1) Conflict inside social movements

- Part of social movements blames other part of social movements of violence, justice obstruction or other conflict.

Register (-1) Conflict between authorities

- Authority blames other authority of violence, institutional violence or justice obstruction.

\section{Relation with victims}

Quotations of victims' families or the victims themselves

(M) Register (1) Against Authorities if there are stories about human rights violations by authorities.

(M) Register (-1) Against Social Movements if explicitly mention to be against social movements.

(N) Register (1) Teamed Authorities if the victims or families explicitly mention authorities are helping, with the investigation, prosecution and achieve good results or with other actions.

(N) Register (-1) Teamed Social Movements if the article explicitly mentions the victim or families are working with NGOs or activists, helped by them, or families participated in at least one protest.

\section{Size of the Target Group (O)}

Register (1) for General target group for all women, it means could happen to anyone. 
Readme. Data set: Testing Protest Paradigm in Femicide Protests in Mexican Press

Register (0) for Socio- Demographic focused target group for women that lives in a specific region, age, ethnics, economic status, profession.

Register (-1) for Situation Involvement target group for women related with organized crime or specific group named as dangerous (drugs dealers, prostitutes related to organized crime, cartels, criminals). 